\title{
Bridging the knowing-doing gap in South Africa and the role of environmental volunteer groups
}

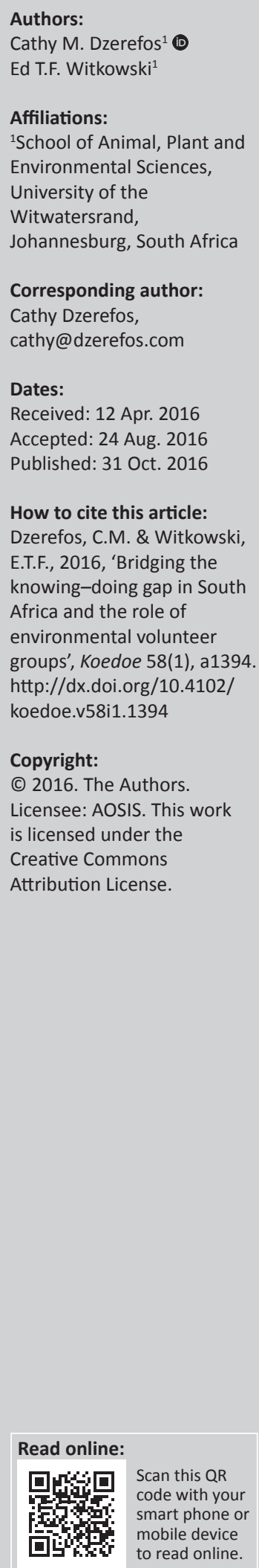

The implementation gap between science, policy and practice has led to loss of biodiversity and ecosystem services throughout Africa and is described in a case study from Limpopo Province, South Africa. In 2006, the South African National Biodiversity Institute first highlighted the Woodbush Granite Grassland (WGG) in the Greater Tzaneen Local Municipality as the only Critically Endangered ecosystem in Limpopo Province. Five years later (2011), the Critically Endangered listing was published in the Government Gazette No. 34809. After repeated and sustained efforts for many years from volunteers of a local environmental group - currently known as the Friends of the Haenertsburg Grassland (FroHG) - in 2015 the intent to formally protect 126 ha was published in the Government Gazette No. 2609. Unfortunately, the proposed protected area accounts for only $66 \%$ of the largest remaining fragment of WGG, which excludes an important colony of medicinal plants. Considering that only $6 \%$ of the original extent of WGG remains in an untransformed state the whole fragment should be conserved. Non-alignment of municipal spatial priorities, as in the Haenertsburg town plan from 1896, to provincial and national environmental priorities has resulted in numerous incidents that have degraded what little remains of the WGG ecosystem. Failure of the provincial authorities to act timeously to enforce environmental regulations resulted in the FroHG successfully involving national authorities to stop illegal land occupation while another incident involving an illegal fence was resolved 9 years after erection. A strengthened relationship with Lepelle Northern Water has resulted in better planning of activities in relation to an existing pipeline. This case study shows various avenues available to environmental volunteer groups in South Africa and suggests that long-term lobbying can yield positive results.

Conservation implications: Formal conservation of WGG through the intended nature reserve proclamation represents application of environmental legislation (notably Listing Notice 3, National Environmental Management Act 107 of 1998: Environmental Impact Assessment Regulations, 2014), scientific recommendations and policy. Better cooperation between provincial administration and FroHG will benefit the protection and management of WGG.

\section{Introduction}

In many parts of Africa, biodiversity (Noss 1990) and functioning ecosystems remain intact (OpioOdongo 2013), providing beneficial plants and animals (Dzerefos, Witkowski \& Kremer-Köhne 2016; Novellie, Biggs \& Freitag-Ronaldson 2013; Sango \& Godwell 2015), water storage and flood retention services (Opio-Odongo 2013), soil carbon and nitrogen (Tesfaye et al. 2016) and areas for tourism or spiritual significance (CER 2015; Dzerefos 2004). To ensure sustainable development necessary to alleviate poverty, unemployment and illiteracy, environmental legislation and implementation are essential to maintain ecological infrastructure (DEA 2013). The translation of science into the decision-making process and practical application by government administration has been identified as obstacles to securing environmental sustainability in Africa (Cowling \& Wilhelm-Rechmann 2007) even in a relatively politically and economically secure country like South Africa, which has holistic and sound environmental legislation (CBD 2014).

Climate change research for sub-Saharan Africa indicates increased frequencies of droughts and flooding impacting negatively on biodiversity and ecosystem services (DEA 2013; Sango \& Godwell 2015). The grassland biome is predicted to be most at risk (Carbutt \& Martindale 2014; DEA 2013; Thompson \& Swemmer 2014) with species responding negatively to habitat fragmentation through anthropogenic activities over a 50- to 100-year time lag (Fourie, Rouget \& Lötter 2015). In response to these predictions, the South African adaptation strategy to climate change recommends securing upper water catchment grasslands to safeguard water storage, flood retention capacity and biodiversity (DEA 2013). Indeed in the last decade, 60000 ha of

Note: This article is dedicated to the Friends of the Haenertsburg Grassland (FroHG) for acting on the words of Archbishop Desmond Tutu 'Do your little bit of good where you are; it's those little bits of good put together that overwhelm the world'. 
grasslands have been proclaimed as protected areas (Carbutt \& Martindale 2014).

The Limpopo Province has one Critically Endangered ecosystem, the Woodbush Granite Grassland (WGG) (Desmet et al. 2013; Mucina et al. 2006; RSA 2011), located in the Greater Tzaneen Local Municipality (GTM), in the foothills of the Northern Drakensberg escarpment (Figure 1). WGG is a source of scarce plants for traditional healing and hand brushes that have regional cultural relevance (Dzerefos et al. 2016). As a mere $1.8 \%$ was conserved (Desmet et al. 2013) and $6 \%$ of the original extent is untransformed (Niemandt 2015), there is a high risk that it will not persist into the future. The largest continuous fragment of WGG, having an area of 192 ha, lies adjacent to the small town of Haenertsburg. It contributes to the headwaters of the Ebenezer Dam (Seshoka, De Lange \& Faysse 2004) through the Kantoor and Wilge Rivers and two natural springs (Moreroa 2014). The second largest WGG patch measures 60 ha and constitutes a peninsular jutting into Ebenezer Dam (Figure 2) and land tenure rests with government. Several much smaller WGG remnants, ranging in size from 5 ha to 25 ha, occur next to the Magoebaskloof Hotel, on privately owned farms or on communal grazing lands. Up until October 2010, the Haenertsburg grassland was under the custodianship of the National Department of Public Works (DPW); thereafter, it was transferred to Limpopo Province. The intention to declare 126 ha $(66 \%)$ of the Haenertsburg grassland a provincial nature reserve was recently published (LPG 2015). The state-owned grasslands are continuous in the south with a private property known as Danallen, which is characterised by three small patches of Northern Mistbelt Forest (Mucina \& Geldenhuys 2006) and drops steeply towards the Wilge River. The government and private-owned land have no fences between them, and the Louis Changuion hiking trail traverses both. Sections of WGG adjoin pine plantations and there is an active fire management programme spearheaded by the timber industry (Dzerefos et al. 2016), which has resulted in a network of firebreaks and roads stretching from remote areas in the Drakensberg escarpment to the lowlands. The WGG and the Ebenezer Dam are separated by an important arterial route (the R528) between Polokwane and Tzaneen. The Ebenezer Dam is a significant water source, supplying the provincial capital, Polokwane, $60 \mathrm{~km}$ away, as well as rural settlements along the R528 with potable water (Seshoka et al. 2004). Haenertsburg town and most outlying

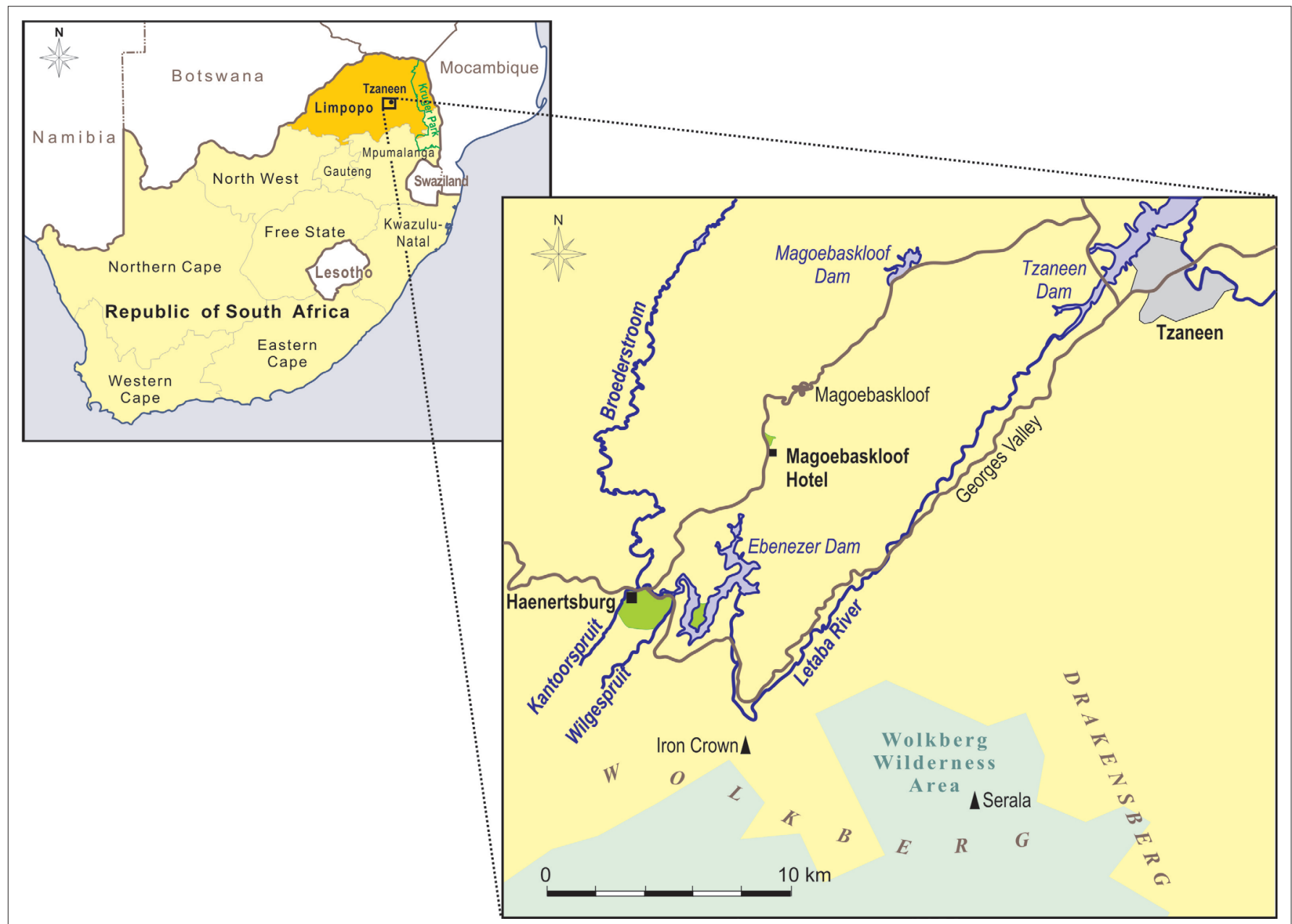

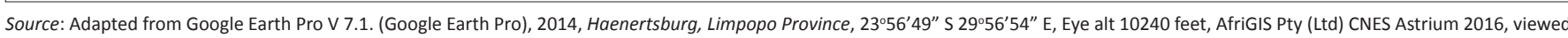
26 January 2016

FIGURE 1: Haenertsburg town with Woodbush Granite Grassland patches (in green) located in the foothills of Wolkberg Wilderness area, northern Drakensberg escarpment, Mopani District, Limpopo Province, South Africa. 


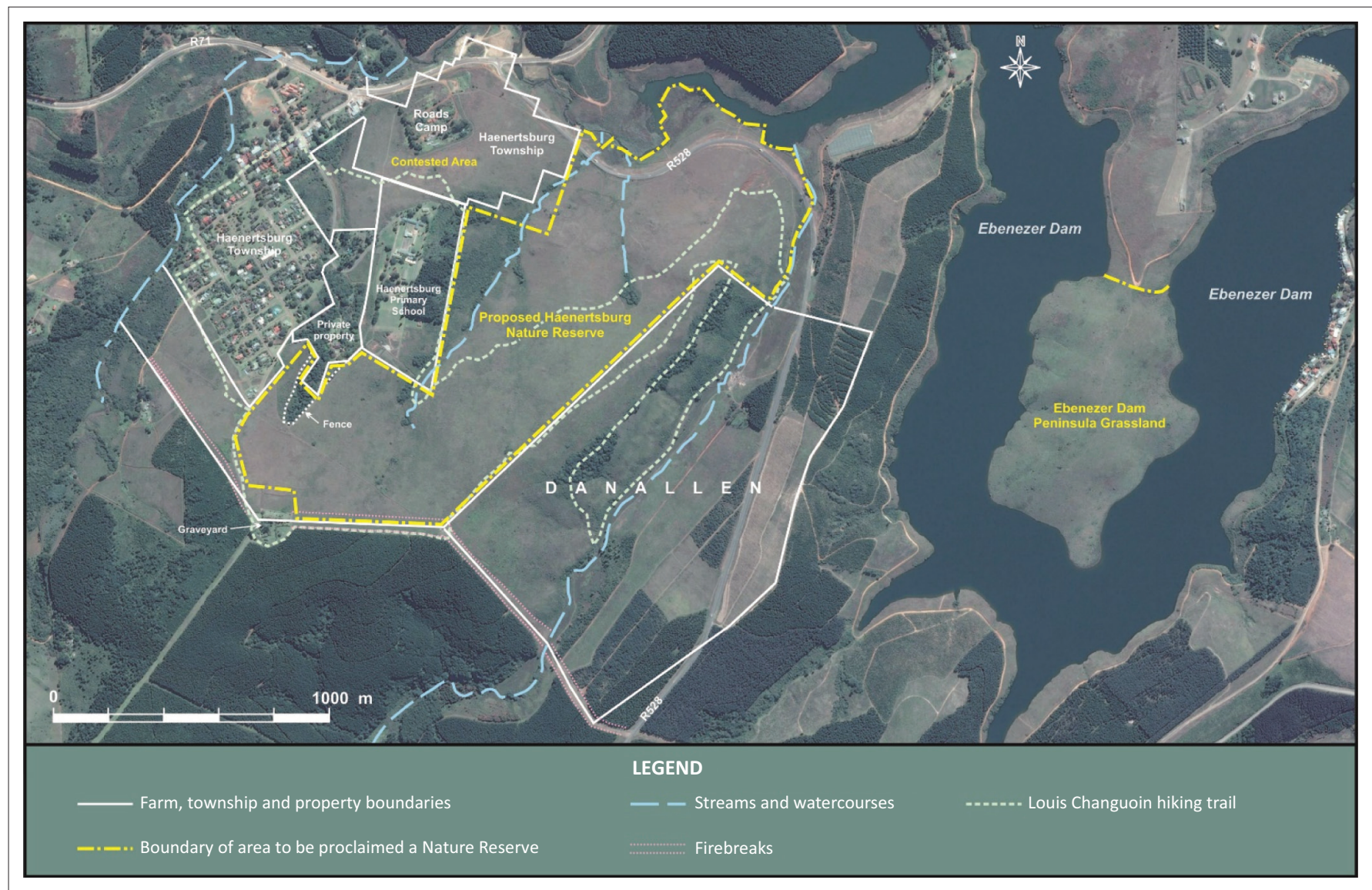

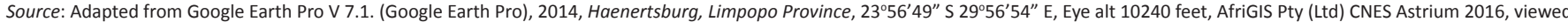
26 January 2016

Land-use cover (urban development, plantations, natural areas), associated infrastructure, water bodies, the location of the illegal fence and the Louis Changuion hiking trail which traverses the farm Danallen (under private tenure) are shown. The contested area denotes the $34 \%$ of the largest fragment that has been excluded from the proposed Haenertsburg Nature Reserve and where illegal land sales had taken place and a source of medicinal plants exists.

FIGURE 2: Google Earth Pro image (2015) of the two largest remaining Woodbush Grassland fragments under public tenure.

residential plots and tourist developments in the area do not have adequate sewage management and use septic tanks and French drains (Spatial Development Framework [SDF] 2009), which could pollute groundwater. The Letaba River is the natural outflow conduit of Ebenezer Dam and serves numerous downstream users in the water-limited lowland areas including rural communities, industry and agriculture. Over a decade ago, the water demands on the Letaba River were found to exceed the capacity of the river (Seshoka et al. 2004), which suggests that downstream water users who are further from the Ebenezer Dam, like the Kruger National Park and rural communities in Mozambique, may not receive sufficient water.

Within the broader study area, steep altitudinal gradients that influence temperatures, frost and precipitation in conjunction with variable soil types lead to juxtaposition of habitats suitable for subtropical (avocado) and temperate (kiwi and blueberry) crops. This distinction is mirrored in the timber plantations, where pine grows optimally in the wetter areas and Eucalyptus in the drier areas. Towards Polokwane in the west, the climate is hotter, drier and frost free and supports savannah vegetation. In contrast, a grassland-forest mosaic occurs in cooler, high-rainfall areas in the Drakensberg escarpment and associated hills, such as where WGG occurs.
The highest point in the escarpment, known as the Iron Crown $(2126 \mathrm{~m})$ is a mere $6 \mathrm{~km}$ from Haenertsburg, which is located in undulating hills. A 40-km north-east descent along the R528 ends at an altitude of $752 \mathrm{~m}$ in Tzaneen. Tzaneen is known for its warm, humid, frost-free climate, which supports citrus, mango and litchi orchards. A distinct easterly rainfall gradient exists from the escarpment to the drier Lowveld area and Kruger National Park. The milder climate of Haenertsburg and immediate surroundings contributes to a tourism industry specialising in adventure sport, mountain biking, hiking and boating activities.

The National Environmental Management: Biodiversity Act (2004), provides for listing threatened ecosystems, in order to reduce ecosystem and species extinction, by preventing further degradation in areas with exceptionally high conservation value (RSA 2011). Biodiversity targets, to prevent loss of threatened species, have been calculated for South African ecosystems and are necessary for biodiversity planning, monitoring and management (CBD 2014). In South Africa, biodiversity targets are determined using the SpeciesArea Relationship, which results in a higher biodiversity target for species-rich ecosystems relative to species-poor ones (Desmet \& Cowling 2004). Hence, for WGG, a higher biodiversity target of $27 \%$ was set, relative to the $23 \%$ average 
for other ecosystems in Limpopo (Desmet et al. 2013; Mucina et al. 2006) and 20\% internationally. However, already 10 years ago, Mucina et al. (2006) stated that WGG was Critically Endangered and this target cannot be met as only about $10 \%$ remained in a natural state. Furthermore, WGG was prone to bush encroachment arising from both sour bushveld and scrub forest, which is compounded by fire exclusion (Mucina et al. 2006) and climate change (Thompson \& Swemmer 2014). Large parts of WGG had been planted to exotic timber since the early 1900s (Dzerefos 2004) or developed for agriculture, housing or tourism (Moreroa 2014). More recently, a study of aerial photographs from 1948, 1977 and 2008, together with some ground truthing of land cover, where access to land was possible, indicated that only $6 \%$ of the original WGG remains untransformed (Niemandt 2015). Using remote sensing to assess WGG, Desmet et al. (2013) calculated $45 \%$ as still intact, but this includes the whole forest-scrub-grassland mosaic as a functional management unit, whereas Niemandt (2015) only considered the grassland areas. Furthermore, the $6 \%$ was likely to be an over-estimate as some wetland and degraded areas may have been included as they could only be distinguished through site visits, which were not possible for the whole extent (Niemandt 2015). The protection of grassland biodiversity has the simultaneous benefit of securing ecosystem services by increasing water capture and storage for lower catchments (Carbutt \& Martindale 2014).

The National Environmental Management: Protected Areas Act (2003) and the National Protected Area Expansion Strategy (CBD 2014) are existing mechanisms that could have formally been used to secure the WGG. Unfortunately, prior to the study by Mucina et al. (2006), the description of WGG did not exist and it was included in the widespread North-Eastern Mountain Grassland occurring from Limpopo southwards to Kwa-Zulu Natal and the Eastern Cape (Low \& Rebelo 1996). Even if WGG was recognised at the time, it may have been excluded because it is highly fragmented.

South Africa has a parliamentary system, operating at national, provincial (nine provinces) and local (district and local municipalities) government levels with an independent judiciary (Rossouw \& Wiseman 2004). National, provincial and local levels of government have distinct but interrelated legislative and executive authority (Figure 3; Novellie et al. 2013) governed by values enshrined in the Constitution. Provincial environmental legislation, such as the Limpopo Environmental Management Act (LEMA) (Act 7 of 2003) calls for sustainable and managed use of important biodiversity areas where natural resources are collected. Government officials working in the environmental field through national or provincial legislation give effect to the international commitments, which South Africa has signed, such as the Convention on Biological Diversity (CBD 2014). Hence, performance and delivery on environmental mandates at the provincial level are of national relevance (CER 2015; Moreroa 2014; Rossouw \& Wiseman 2004; Wilhelm-Rechmann \& Cowling 2013).

Provincial authorities are mandated to advise local municipalities on ecological and conservation priorities required in the land-use planning process (WilhelmRechmann \& Cowling 2013) and infrastructure provision. For instance, the Spatial Planning and Land Use Management

\section{NATIONAL}

The Constitution of the Republic of South Africa (Act 108 of 1996) states in section 24 that the environment must be protected for the benefit of the present and future generations through reasonable legislative measures that prevent pollution and ecological degradation and promote conservation, sustainable development and use of natural resources, while promoting justifiable economic and social development.

\begin{tabular}{|c|c|c|c|c|c|}
\hline \multirow{2}{*}{ 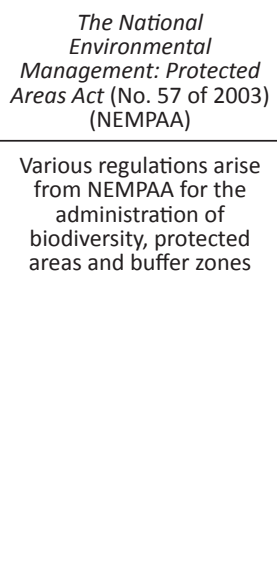 } & \multicolumn{4}{|c|}{ National Environmental Management: Biodiversity Act (No. 10 of 2004) (NEMBA) } & \multirow{2}{*}{$\begin{array}{l}\text { National Environmental } \\
\text { Management Act } 107 \text { of } \\
\text { 1998: Environmental } \\
\text { Impact Assessment } \\
\text { Regulations, } 2014 \text { (NEMA) } \\
\text { Regulates listed activities } \\
\text { requiring authorisation } \\
\text { prior to commencement, } \\
\text { particularly in threatened } \\
\text { and protected ecosystems, } \\
\text { by independent specialist } \\
\text { consultants to evaluate } \\
\text { known information, } \\
\text { undertake fieldwork and } \\
\text { collate public inputs. On } \\
\text { the basis of findings and } \\
\text { recommendations, the } \\
\text { province will determine } \\
\text { whether a proposed } \\
\text { development can proceed } \\
\text { and will also consider any } \\
\text { appeals lodged }\end{array}$} \\
\hline & $\begin{array}{l}\text { Section } 38 \text { requires a } \\
\text { National Biodiversity } \\
\text { Framework to provide an } \\
\text { integrated approach to } \\
\text { biodiversity management } \\
\text { and arose from South } \\
\text { Africa's commitment in } \\
\text { terms of the UN } \\
\text { Convention on Biological } \\
\text { Diversity }\end{array}$ & $\begin{array}{l}\text { Section } 43 \text { makes provision } \\
\text { for Biodiversity } \\
\text { Management Plans (BMPs) } \\
\text { at ecosystem or species } \\
\text { level }\end{array}$ & $\begin{array}{l}\text { Section } 45 \text { requires } \\
\text { monitoring and reporting } \\
\text { on the implementation } \\
\text { and progress of the } \\
\text { Biodiversity Management } \\
\text { Plan by the provincial } \\
\text { authority }\end{array}$ & $\begin{array}{l}\text { Section } 52 \text { requires a } \\
\text { national list of ecosystems } \\
\text { that are threatened and in } \\
\text { need of protection }\end{array}$ & \\
\hline \multicolumn{6}{|c|}{ PROVINCIAL } \\
\hline \multicolumn{6}{|c|}{$\begin{array}{c}\text { The Limpopo Environmental Management Act (No. } 7 \text { of 2003) (LEMA) gives the Member of the Executive Council authority to declare a Site of Ecological Importance or a } \\
\text { protected area and to obtain land for that purpose. }\end{array}$} \\
\hline \multicolumn{6}{|c|}{ MUNICIPAL/LOCAL } \\
\hline
\end{tabular}

Environmental legislation administered by Department of Agriculture and the Department of Forestry and Fisheries respectively have been excluded for the sake of simplification. FIGURE 3: The framework within which environmental departments fulfil their mandates to protect biodiversity and ecosystem services, which is guided by policies and legislation which arise from the Constitution, 1996 and inform national and provincial legislation. 
Act (No. 16 of 2013) requires local government to prepare a Spatial Development Plan (SDP) (RSA 2013). Legislation such as LEMA as well as specialist sector reports, such as the Limpopo conservation plan (Desmet et al. 2013), should inform decision-making processes and guide the compilation of the SDF every 5 years (RSA 2013; SDF 2009; WilhelmRechmann \& Cowling 2013).

The Limpopo Province Department of Economic Development, Environment and Tourism (LEDET) is an organ of state accountable for the conservation of provincial natural areas (Anthony, Scott \& Antypas 2010). The provincial Premier appoints a Member of the Executive, from among the provincial legislature, to head provincial departments. Typically, the term of office is 5 years. Since 2000, a community-based volunteer group, initially known as Haenertsburg Environmental Monitoring and Action Group (HEMAG) and currently known as Friends of the Haenertsburg Grassland (FroHG), have actively engaged with LEDET to ensure that biodiversity and ecosystem services of WGG are not compromised and environmental regulations enforced. As of March 2016, FroHG had 81 paid-up members, who are environmentally aware residents with skills such as ecotourism, horticulture, farming, mapping and education. Traditional healers and hand brush harvesters from a wider area have also been shown to greatly value this grassland's biodiversity as it has cultural and economic value (Dzerefos et al. 2016). This case study, of Limpopo Province's only Critically Endangered ecosystem, WGG, is used to show how current legislation offers the required framework for specialist knowledge to be realised and the stewardship role that environmental volunteer groups can offer.

\section{Methods \\ Historical records}

Using the archives of the community-based, environmental group FroHG, letters and emails to authorities, as well as memos, reports and government gazettes pertaining to WGG were consulted. Individuals and groups that had a known interest in lobbying on behalf of WGG were contacted to contribute records of correspondence and the subsequent replies that were received from provincial authorities. Letters collected date back to 1988 but the historical record peaks from 2005 when email communication predominated and HEMAG (now FroHG) lodged a submission to LEDET to have the Haenertsburg grassland proclaimed a Site of Ecological Importance through LEMA.

Records reporting illegal activities on WGG have also been kept. The most significant was the fencing of public land by an adjacent landowner in 2007 (Figure 2) and the demarcation and selling of small plots in 2011 (Troskie 2011). The email correspondence was arranged in terms of date, designation of recipient, organisation, subject and whether the matter was resolved. If the email was forwarded by the recipient to another person, this person was added to the database and because the recipient was copied on the email, it was logged that the initial person had replied. Keeping a detailed record of correspondence with authorities identifies where and when there was a breakdown in communication and service delivery. These results are conservative estimates of communications as telephonic discussions and site inspections were unrecorded. Moreover, the regional manager of the Wildlife and Environment Society of South Africa, a national non-profit organisation involved in biodiversity protection, had also corresponded with provincial and local authorities from 2008 to 2011, but unfortunately these records were deleted when the post became vacant. Nonetheless, overall these records provide an important historical accounting of the various efforts made and responses received.

\section{Important role players}

Key events pertaining to the Haenertsburg grassland were arranged in a timeline so that the performance of key role players could be easily viewed. To quantify efficiency and accountability, outstanding responses on issues pertaining to WGG were followed up with the three tiers of government, namely the National Environmental Crimes and Incidents Hotline (Env-hotline), the Limpopo legislature (Public Participation and Petitions Unit) and LEDET, between June 2014 and March 2016. The Env-hotline, operated by the National Department of Environmental Affairs, is an avenue for the public to report non-compliance with environmental legislation (CER 2014). Replies or non-replies were documented. All parties were informed of this research project and copies of past emails detailing relevant information were sent to recipients for ease of reference. LEDET was invited to discuss the research method but there was a 4-month time delay before they responded, by which time data collection and analysis of available historical information had been completed. Nonetheless, as the paper was written and reviewed, LEDET officials were provided with opportunity to comment and provide input.

\section{Historical town plan}

In mid-2014, images appearing on Google Maps of Haenertsburg village and the adjacent grassland indicated settlement demarcations envisaged in the 1890s in areas of pristine WGG. The findings of the Limpopo conservation plan (Desmet et al. 2013) and land cover assessment of WGG (Niemandt 2015), as well as inputs from traditional plant users (Dzerefos et al. 2016), suggest that the original town plans should be aligned with national and provincial environmental priorities. This process requires the intervention of LEDET. The outdated information was reported to Google Maps on 22 July 2014, by clicking on the 'Report a problem' icon located at the bottom right of the image and also to the GTM town planners.

\section{Results Historical timeline}

High levels of transformation of WGG are evident from the 1970s (Niemandt 2015) and coincide with the first letters 
sent to the authorities highlighting the importance of WGG. These letters were written by community members, the curators of two herbaria, the Botanical Society of southern Africa and biodiversity specialists employed by the provincial government (Table 1). Financial support from the National Lottery Distribution Trust Fund allowed HEMAG to commission environmental education resources, biodiversity studies and an Environmental Management Plan (EMP) in 2004, according to National Environmental
Management Act 107 of 1998: Environmental Impact Assessment Regulations, 2014 (NEMA). A LEDET ecologist commended the EMP and recommended the inclusion of more areas. In 2005, HEMAG lodged a formal submission to LEDET to declare the WGG around Haenertsburg town a Site of Ecological Importance. LEDET officials, specialising in botany and herpetology, conducted investigations and recommended upscaling the proclamation to a nature reserve.

TABLE 1: Chronology of events pertaining to the largest remaining continuous section of Woodbush Granite Grassland, adjacent to Haenertsburg village, Limpopo Province.

\begin{tabular}{|c|c|c|c|c|}
\hline$\underline{\text { Date }}$ & Anti-grassland events & Pro-grassland events & Science & Policy \\
\hline 1887-1910 & $\begin{array}{l}\text { Discovery of gold and founding of } \\
\text { Haenertsburg (Changuion 2007) } \\
\text { results in felling of indigenous forest } \\
\text { trees to support mining industry } \\
\text { regionally (Dzerefos 2004) }\end{array}$ & - & - & $\begin{array}{l}\text { The Transvaal Dept. of Agriculture } \\
\text { and Forestry plants exotic pine and } \\
\text { Eucalyptus in what is described at } \\
\text { the time as 'unimproved grassland' } \\
\text { (Dzerefos 2004) for sustainable } \\
\text { timber }\end{array}$ \\
\hline 1970-2000 & $\begin{array}{l}\text { Based on the premise that low } \\
\text { fuel-load results in 'cool' fires that are } \\
\text { easier to control, the grassland is } \\
\text { burnt annually to protect plantations } \\
\text { and homes }\end{array}$ & $\begin{array}{l}\text { Individuals raise awareness through } \\
\text { letters, petitions, wildflower } \\
\text { paintings and lobbying authorities. } \\
\text { The Louis Changuion hiking trail ( } 9 \\
\mathrm{~km} \text { ) was founded in } 1980 \text { to prevent } \\
\text { the area from being sold and } \\
\text { developed. In } 1999 \text {, volunteers form } \\
\text { the Haenertsburg Environmental } \\
\text { Monitoring and Action Group } \\
\text { (HEMAG) }\end{array}$ & $\begin{array}{l}\text { In 1988, Lynette Davidson, curator of } \\
\text { the CE Moss Herbarium, University } \\
\text { of the Witwatersrand, Johannesburg, } \\
\text { along with over } 100 \text { petitioners } \\
\text { object to planting of exotic trees in } \\
\text { grasslands. Pieter Winter, curator of } \\
\text { the Larry Leach Herbarium, } \\
\text { University of Limpopo, compiles a } \\
\text { list of } 661 \text { plant species in } 192 \text { ha of } \\
\text { Woodbush Granite Grassland (WGG) }\end{array}$ & $\begin{array}{l}\text { Dept. of Environmental Affairs } \\
\text { promotes planting of timber } \\
\text { plantations in WGG. In 1990, Dr } \\
\text { Warwick Tarboton (Transvaal } \\
\text { Directorate of Nature Conservation) } \\
\text { objects in a letter to national } \\
\text { authorities }\end{array}$ \\
\hline 2001-2005 & $\begin{array}{l}\text { A trench for a water pipeline is } \\
\text { mechanically dug by the Greater } \\
\text { Tzaneen Local Municipality (GTM) and } \\
\text { destroys an unknown number of the } \\
\text { endemic Aloe lettyae }\end{array}$ & $\begin{array}{l}\text { National Lotteries funding results in } \\
\text { an Environmental Management Plan } \\
\text { (EMP). } \\
\text { Botanical Society of SA (BotSoc) } \\
\text { highlights importance in a letter to } \\
\text { the municipality. Submission to } \\
\text { Limpopo Dept. of Economic } \\
\text { Development, Environment and } \\
\text { Tourism (LEDET) to declare } \\
\text { Haenertsburg grassland a Site of } \\
\text { Ecological Importance }\end{array}$ & $\begin{array}{l}\text { LEDET botanist and herpetologist } \\
\text { conduct investigations and } \\
\text { recommend a nature reserve while } \\
\text { the ecologist commends the EMP } \\
\text { and suggests a larger area be } \\
\text { included }\end{array}$ & $\begin{array}{l}\text { The Limpopo Environmental } \\
\text { Management (LEMA) (Act } 7 \text { of 2003) } \\
\text { details how to declare a protected } \\
\text { area }\end{array}$ \\
\hline 2006 & $\begin{array}{l}\text { GTM clears WGG around the water } \\
\text { reservoir to establish a park. More } A \text {. } \\
\text { lettyae are lost }\end{array}$ & $\begin{array}{l}\text { Submission to LEDET to declare } \\
\text { Haenertsburg grassland a nature } \\
\text { reserve. HEMAG produces } \\
\text { information pamphlets, a trail map } \\
\text { and manages the grassland } \\
\text { according to the EMP. Signage } \\
\text { erected to deter off-road vehicles }\end{array}$ & $\begin{array}{l}\text { WGG described as irreplaceable and } \\
\text { Critically Endangered (Mucina \& } \\
\text { Rutherford 2006) }\end{array}$ & $\begin{array}{l}\text { BotSoc details steps LEDET should } \\
\text { follow for declaration }\end{array}$ \\
\hline 2007 & $\begin{array}{l}\text { Adjacent landowner bulldozed } \\
\text { grassland-forest margin to erect a } \\
\text { fence (Moreroa 2014). LEDET does } \\
\text { not take action and refers matter to } \\
\text { the owner of the land Dept. of Public } \\
\text { Works (DPW) }\end{array}$ & $\begin{array}{l}\text { A petition of } 165 \text { community } \\
\text { members is signed against illegally } \\
\text { erected fence and submitted to } \\
\text { Provincial legislature. HEMAG } \\
\text { changes name to Friends of the } \\
\text { Haenertsburg Grassland (FroHG) }\end{array}$ & - & $\begin{array}{l}\text { The GTM Spatial Development } \\
\text { Framework calls for protection and } \\
\text { environmental monitoring of WGG } \\
\text { because of plant use by } \\
\text { impoverished communities (SDF } \\
\text { 2009) }\end{array}$ \\
\hline 2008-2009 & $\begin{array}{l}\text { Occupants of the DPW houses, } \\
\text { harvest wood from forest and } \\
\text { annually plant maize (Zea mays). } \\
\text { Telkom bulldozes an unauthorised } \\
\text { trench to lay cables through WGG }\end{array}$ & $\begin{array}{l}\text { The illegal fence was vandalised. } \\
\text { Lepelle Northern Water (LNW) } \\
\text { regional manager signs the EMP }\end{array}$ & $\begin{array}{l}\text { South African Environmental } \\
\text { Observation Network (SAEON) sets } \\
\text { up climate change monitoring plots } \\
\text { on two WGG fragments (Thompson } \\
\text { \& Swemmer 2014) }\end{array}$ & $\begin{array}{l}\text { Member of the Executive (MEC) of } \\
\text { (LEDET) visits the WGG and promises } \\
\text { to expedite the reserve application } \\
\text { process }\end{array}$ \\
\hline 2010-2011 & $\begin{array}{l}\text { Unauthorised housing plot } \\
\text { demarcations (Troskie 2011) are } \\
\text { ignored by LEDET and the South } \\
\text { African Police Service (SAPS). SANBI } \\
\text { involves the Select Committee Land } \\
\text { and Environmental Affairs Parliament } \\
\text { of South Africa who instruct LEDET to } \\
\text { take action. LNW cuts a new road } \\
\text { next to existing pipeline }\end{array}$ & $\begin{array}{l}\text { Item } 28(1) \text { certificate for portion } 3 \\
\text { and remainder of Haenertsburg } \\
1103-\text { SS is approved by Dept. of } \\
\text { Rural Development and Land } \\
\text { Reform in October 2010, which } \\
\text { allowed DPW to transfer land to } \\
\text { LEDET for the purpose of a nature } \\
\text { reserve. Maps for the proposed } \\
\text { reserve were submitted to the } \\
\text { Surveyor-General's Office }\end{array}$ & - & $\begin{array}{l}\text { WGG as per the National } \\
\text { Environmental Management: } \\
\text { Biodiversity Act (2004): National List } \\
\text { of ecosystems is listed as threatened } \\
\text { and in need of protection (RSA 2011) }\end{array}$ \\
\hline 2012-2013 & $\begin{array}{l}\text { In March 2012, LNW dug a } 200 \text { X 6-m } \\
\text { trench for a water pipeline (Brown \& } \\
\text { Cook 2012; Moreroa 2014). Four } \\
\text { protected plant species, A. lettyae, } \\
\text { Brachystelma oianthum, Ceropegia } \\
\text { meyeri and Eulophia parvilabris were } \\
\text { damaged. Steven's Lumber Mill (SLM) } \\
\text { tilled a fire break tracer through a } \\
\text { colony of Merwilla plumbea and } \\
\text { uprooted between } 350 \text { and } 400 \text { bulbs } \\
\text { as well as A. lettyae }\end{array}$ & $\begin{array}{l}\text { FroHG secures national funding for } \\
\text { alien plant clearing. Illegal staking } \\
\text { out of plots attempted in February } \\
2013 \text { but stopped by the SAPS }\end{array}$ & $\begin{array}{l}\text { In November 2012, a LNW report } \\
\text { urged removal of alien vegetation } \\
\text { and rehabilitation of pipeline trench } \\
\text { dug without environmental } \\
\text { authorisation in March (Brown \& } \\
\text { Cook 2012). SAEON conducts second } \\
\text { monitoring of WGG plots (Thompson } \\
\text { \& Swemmer 2014) }\end{array}$ & - \\
\hline 2014-2016 & $\begin{array}{l}\text { Google Maps shows outdated town } \\
\text { plans for Haenertsburg expansion but } \\
\text { changes these when alerted. Illegal } \\
\text { fence vandalised and SLM scrapes a } \\
\text { firebreak impacting Eulophia hians } \\
\text { and Indigofera rehmannii }\end{array}$ & $\begin{array}{l}\text { FroHG and local Rotary commission } \\
\text { a specialist to re-evaluate the fire } \\
\text { plan. Provincial legislature rules the } \\
\text { fence illegal and DPW enforces } \\
\text { removal. LNW appoints a specialist } \\
\text { team to mitigate impacts of existing } \\
\text { pipeline }\end{array}$ & $\begin{array}{l}\text { Tshwane University and the } \\
\text { University of the Witwatersrand } \\
\text { undertake botanical research in } \\
\text { WGG }\end{array}$ & $\begin{array}{l}\text { MEC of LEDET visits WGG and } \\
\text { publishes intention to declare } 66 \% \\
\text { of the largest remaining fragment a } \\
\text { nature reserve (LPG 2015) }\end{array}$ \\
\hline
\end{tabular}

Incidents relating to other Woodbush Granite Grassland patches have occurred in the time period under consideration but have not been included due to space constraints. 
From 2006 to 2013 (Table 1), a number of degrading events occurred in the Haenertsburg grassland, which led to loss of biodiversity and public frustration with environmental law enforcement. In an attempt to stop damage to the grassland, HEMAG erected no entry signage, indicating that it was a Site of Ecological Importance. Although this may have reduced off-road vehicle use, other misdemeanours continued. For example, a landowner having a residential property next to the grassland and the Haenertsburg Primary School bulldozed the grassland-forest margin to erect a fence on public property. Although FroHG (previously HEMAG) raised objections with the GTM (having a land-use planning responsibility) (WilhelmRechmann \& Cowling 2013), LEDET (having the responsibility to uphold environmental legislation and advise GTM on biodiversity priorities) and the DPW (land custodian until October 2010), each administrative body passed responsibility to the other. FroHG sent 33 emails regarding the fence, between October 2007 and December 2008 to LEDET and had a response rate of $42 \%$. Because of the failure of provincial department intervention in the fence matter, it was reported to the Public Participation and Petitions Unit for Limpopo Province by means of a petition signed by 165 individuals. The matter was heard by the petitions committee in July 2015, which ruled the fence illegal and instructed DPW to ensure that the fence be removed. The matter took 8 years to be heard during which time illegal sections of the fence were vandalised twice and antelope kept on the property escaped. The petitions committee ruling was implemented in September 2016 (Table 2).

Another incident, reported on in provincial newspapers, involved the illegal staking out and selling of 25 plots on the Haenertsburg grassland by an individual claiming ownership of the area below the Haenertsburg Primary School (Troskie 2011). The local and provincial authorities were immediately notified and provided with photographic evidence of unearthed grassland plants. The Environmental Compliance and Enforcement division of LEDET responded that it was not possible to issue a directive to the South African Police Service (SAPS) to stop the sub-division of land because the reserve application was not finalised and referred the FroHG to the custodian of the land, the DPW. Because of the lack of environmental capacity in DPW, the loss of protected and threatened biodiversity was not viewed as a matter of urgency and there was no indication that the matter would be attended to. Consequently, the FroHG alerted the South African National Biodiversity Institute (SANBI), a national parastatal involved in biodiversity research, planning and policy. SANBI urgently referred the matter to the Select Committee Land and
Environmental Affairs, Parliament of South Africa (operational from May 2009 to March 2014), which along with the Public Protector and the land claims office persuaded LEDET that it was their responsibility to intervene. LEDET then issued an official directive to the SAPS indicating that the demarcations were illegal and should be stopped. The SAPS and the GTM dismantled one of the shacks that had been erected and the stakes, marked with 'buyers' surnames, were removed. The Office of the Chief Land Claims Commissioner, in a letter to the Select Committee dated December 2011, confirmed that the area was being investigated as part of a land claim made by the Mmamabolo community. The letter confirmed that the staking of land had been done illegally, by an opportunist not of the Mmamabolo community. Because of the discriminatory legislation of the past, many communities had lost ancestral lands throughout South Africa. A process was started in 1994 to research land claims and compensate dispossessed people. The staking out of plots was repeated in February 2013 by the same person, but was promptly stopped by the SAPS who remembered the directive from 2011.

\section{Yester year and current maps}

The original town plan of Haenertsburg, as surveyed in September 1887 (Figure 4), was approved by the acting Surveyor-General in March 1888. Most of the town plan has been realised with the exception of the eastern section, below the Haenertsburg Primary School. A few houses were built for DPW employees near the R528 but most of the section was not developed as the biotite granite extrusions proved too costly to build on. The rocks have acted as grassland fire refugia and a large colony of the medicinal plants, Merwilla plumbea (Blue Squill) (Dzerefos 2004) as well as Boophone disticha (Bushman Poison Bulb), occur there. The eastern section is likely to hold the highest concentration of IUCN Red List category plants in the Haenertsburg grassland and was also the area where land was illegally demarcated and sold (Troskie 2011). The town plan that appeared on Google Maps in 2014 for the eastern section was removed by Google when they were alerted to the status of the ecosystem. GTM indicated that the existing town plan could only be formally aligned with biodiversity priorities through provincial government intervention, notably the proclamation of the proposed reserve.

\section{Good news in half-measure}

Notice of the intention to declare $66 \%$ of the largest remaining fragment of WGG, a nature reserve, was published in the Government Gazette No. 2609 (LPG 2015) and no objections

TABLE 2: Follow up of outstanding issues with the National Environmental Crimes and Incidents Hotline, the Limpopo Legislature Public Participation and Petitions Unit and Limpopo Department of Economic Development, Environment and Tourism from June 2014 to September 2016.

\begin{tabular}{|c|c|c|c|c|c|}
\hline Public body & Content & Emails sent & Number of replies & Matter resolved & Standing of matter \\
\hline $\begin{array}{l}\text { National Environmental } \\
\text { Hotline }\end{array}$ & $\begin{array}{l}\text { Reserve proclamation and fence (Ref: } \\
222920140611091114 \text { ) }\end{array}$ & 8 & 5 & Partly & $\begin{array}{l}\text { The turnaround time for feedback } \\
\text { from LEDET depends on the } \\
\text { complexity of the matter }\end{array}$ \\
\hline $\begin{array}{l}\text { Public Participation and } \\
\text { Petitions Unit }\end{array}$ & $\begin{array}{l}\text { Illegal fence erected in } 2007 \text { and } \\
\text { petition signed by } 165 \text { people }\end{array}$ & 6 & 3 & Yes & Rectified September 2016 \\
\hline LEDET & Reserve proclamation dating to 2006 & 83 & 19 & Partly & $\begin{array}{l}\text { Intention to declare } 66 \% \text { a nature } \\
\text { reserve (LPG 2015) }\end{array}$ \\
\hline
\end{tabular}

Source: Email records Friends of the Haenertsburg Grassland Archives

LEDET, Limpopo Province Department of Economic Development, Environment and Tourism. 


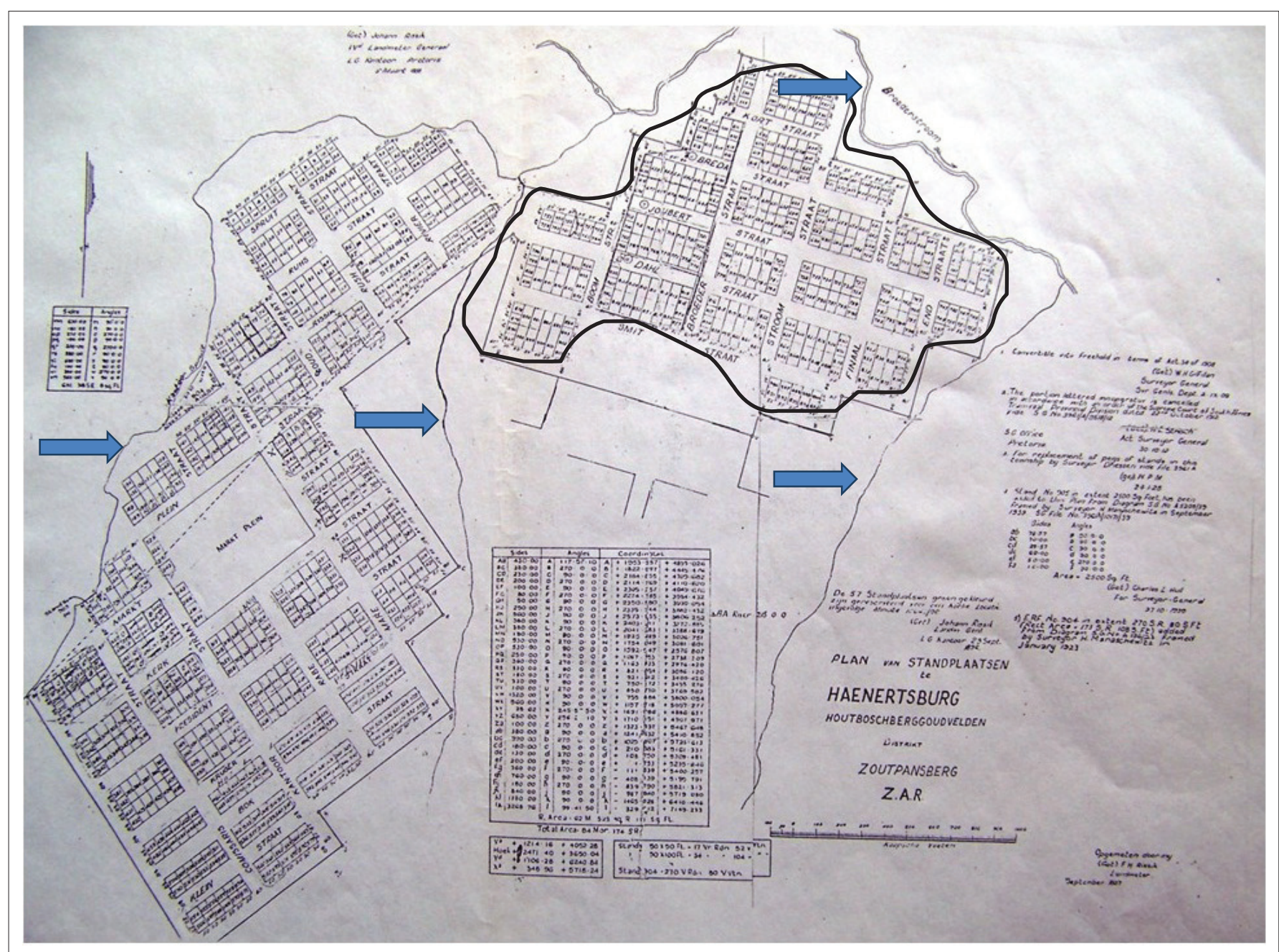

Source: Surveyor-General Office, 1887, Haenertsburg, Houtboschberg, Goudvelden, approved by the acting Surveyor-General, Pretoria, 05 March 1888

FIGURE 4: The original town plan of Haenertsburg, Limpopo Province, South Africa, as surveyed in 1887. The arrows indicate water drainage lines. The solid line indicates an undeveloped area with important medicinal plants that has been excluded by provincial government from the proposed nature reserve.

were raised by the public. FroHG submitted an application to LEDET to be designated as the management authority of the nature reserve to be declared, which has been received favourably by LEDET. Although these are signs of positive development, it seems a half-measure to not declare the full extent of the largest continuous fragment, which is under state tenure and which spatial configuration analysis has identified as the main source area for the other island patches of WGG (Niemandt 2015). The inclusion of the contested area (Figure 2), which is currently zoned for housing development into the nature reserve, is necessary if LEDET is serious about fulfilling the national biodiversity target for WGG because less than $6 \%$ of the original extent remains (Niemandt 2015). Moreover, the status of WGG in the Limpopo conservation plan commissioned by LEDET suggests that all WGG should be conserved (Desmet et al. 2013).

\section{Discussion}

LEDET has a conservation plan in place (Desmet et al. 2013) and has published the intention to declare the WGG nature reserve (LPG 2015). A decade has elapsed since the local environmental group's submission to have 192 ha of WGG proclaimed a protected area, but only $66 \%$ has been included in the proposed reserve (LPG 2015). Notably, the unprotected $34 \%$, is the area where illegal land sales had taken place (Troskie 2011) and where important medicinal plants are located (Dzerefos et al. 2016; SDF 2009); hence, it is the area that is most in need of protection. As two LEDET biodiversity specialists recommended a WGG reserve in 2005 and the significance of WGG resources to the poor has been highlighted (Dzerefos et al. 2016), senior government officials have no excuse but to recognise the significance of the area unless economic development is being pursued with no regard for socio-environmental issues. This could have been the reason why the illegal squatters (Troskie 2011) were not stopped immediately by LEDET or GTM until the matter was taken to the Public Protector and the Select Committee through SANBI. If the land-use change had not been challenged, an informal settlement could have put the water quality of Ebenezer Dam at risk, threatened numerous protected and beneficial plants and increased vulnerability of the ecosystem to alien invasive plants and soil erosion. The importance of precedence was illustrated in 2013 when illegal demarcation of plots by the same opportunist was promptly stopped by the SAPS who recalled the directive from 2011. 
Despite provisions in terms of the Promotion of Access to Information Act (No. 2 of 2000), whereby the public can, within reason, request information and thereby hold public officials to account (Mfene 2013), government officials simply ignored requests for feedback on minutes of meetings or the reasons for leaving out an important, contiguous section of the proposed WGG reserve. It seems that responding to the public, which has been touted as key to realising a local conservation agenda (Cowling \& Wilhelm-Rechmann 2007; Swemmer \& Taljaard 2011), has not been implemented by LEDET, reinforcing the general impression that government officials are unreliable and unaccountable for poor service delivery (Mfene 2013). Nevertheless, it is very encouraging that LEDET has begun discussion with the FroHG in 2016 to manage the new reserve. Official recognition and support of the FroHG could result in cost-effective, 24/7 on the ground biodiversity protection.

Other South African environmental groups have raised objections over the application of environmental legislation (DEA 2014). Objections follow NEMA appeals process on environmental authorisations at provincial level or escalate to national level in some instances (Figure 5). We perceive that the Env-hotline, although operating as a national monitor and providing a reference number, has limited influence as it merely requests feedback from the provincial administration on the allegation of environmental noncompliance. As resolution and feedback to the complainant is not provided by the Env-hotline, it appears to have limited impact. However, as complaints are counted and published, these may impact on resource allocation (CER 2014), improved service delivery and appointment of Environmental Management Inspectors (EMIs) (DEA 2014). Indeed, in recent years the number of EMIs in Limpopo Province has increased substantially more than any other province, from 75 (in 2011/2012) to 237 (in 2013/2014) (DEA 2014) and it is likely that implementation, compliance and enforcement of policy and legislation will improve in future.

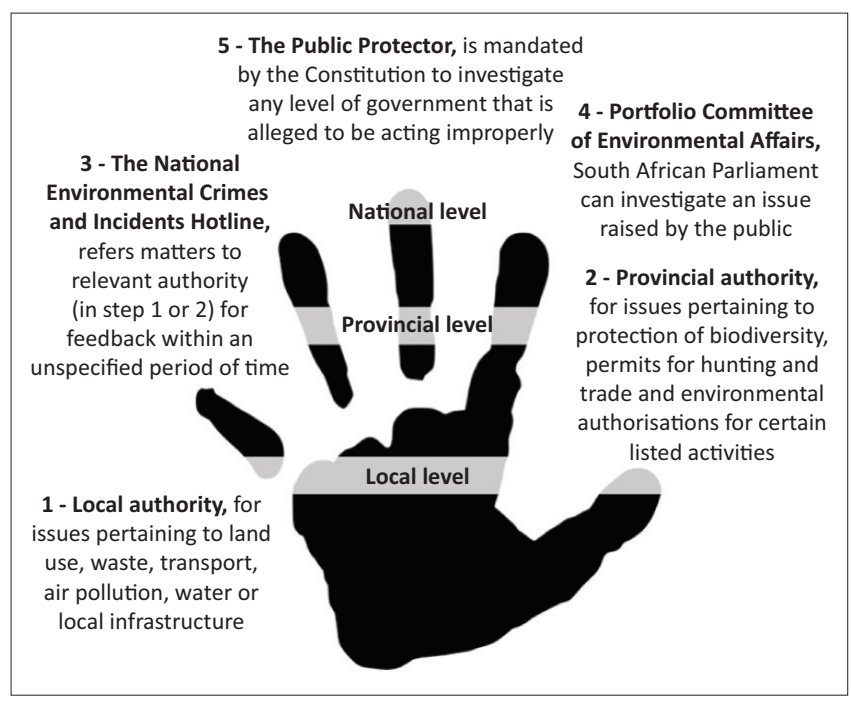

FIGURE 5: A diagrammatic summary of escalating an environmental problem to the three tiers of government (local, provincial and national) to reach a resolution.
Where matters remain unresolved, a court application could be made, but these could be compromised if the judiciary is not familiar with the complexity of environmental threats posed by the breach of environmental law (Moreroa 2014; Young 2012). Environmental law clinics at universities have undergraduate students requiring experiential learning who can take on cases at reduced cost. Alternatively, non-profit organisations, such as the Centre for Environmental Rights, offer affordable advice and assistance for those in financial need. For example, the Traditional Healers Organisation of Africa were dissatisfied with how LEDET handled damage to a sacred area near Thabazimbi and laid criminal charges against the steel mining company's directors (CER 2015). Numerous successful court actions have taken place in recent years such as the Kloof conservancy's landmark victory in the Durban High Court (case number 12667/2012), which holds all levels of government accountable to the Constitution and the law for discharge of environmental duties. Monitoring and evaluation of provincial authorities' outputs and responses to the public should be prompt, transparent and comprehensive so that environmental issues need not be escalated to national level, result in court action or even vandalism.

Relationships between FroHG and other WGG stakeholders have improved over time. Discussion and planning have proven better for public relations than mitigating after biodiversity has been lost. Most notable is the relationship with Lepelle Northern Water (LNW), which post-2013 were involved with maintenance and excavations (Brown \& Cook 2012; Table 1) occurring without an attempt to save threatened or protected plants or plan rehabilitation. In contrast in 2015, LNW appointed MSW Engineering and Project Management Consultants and SRK Consulting to design and plan in consultation with FroHG, how the existing pipeline running through WGG could be repaired and maintained with minimal environmental damage. The agreed approach was to do more than the regulations called for and to engage a botanist to locate and rescue threatened and protected plant species in the area where excavations were planned. The mitigation actions will set a strong precedent of environmental best practice in threatened ecosystems.

Unmonitored plant collection in WGG offers an opportunity to engage with traditional healers and hand brush harvesters who earn a living and fulfil an important socio-economic niche in Limpopo Province (Dzerefos et al. 2016). The Gauteng Directorate of Nature Conservation has demonstrated how a provincial authority can engage constructively with plant users to benefit conservation (Dzerefos \& Witkowski 2001; Taylor \& Atkinson 2012). An adaptive management approach, such as Community-based Natural Resources Management (Opio-Odongo 2013) which includes a medicinal plant nursery, an environmental education centre and a fire management plan (Dzerefos et al. 2016), would contribute to improved environmental awareness and securing water quality of the upper catchment of Ebenezer Dam. The WGG around Haenertsburg could be expanded through the 
Biodiversity Stewardship Programme (BSP). A co-management agreement between LEDET and the owner of the property Danallen, which is continuous with the pending nature reserve, could result in a win-win situation, in terms of removal of alien vegetation, resources to manage fire threat and the existing hiking trail. Since 2002, BSP has been implemented throughout South Africa except for Limpopo Province (Carbutt \& Martindale 2014). BSP assists land owners adjacent to protected areas to take advantage of the Local Government Municipal Property Rates Act (2004), which states that a municipality may not levy a rate on a special nature reserve as long as it is not developed or used for commercial, business, agricultural or residential purposes.

\section{Conclusion}

The identification of areas (Mucina et al. 2006; Niemandt 2015) that require protection are aligned with national legislation on Critically Endangered ecosystems (RSA 2011) and the Limpopo Province conservation plan (Desmet et al. 2013). Implementation of the conservation plan may enhance connectivity between habitat patches, which is essential for the conservation of viable grasslands (Desmet et al. 2013; Fourie et al. 2015). Effective land-use planning is achievable as good habitat connectivity exists through water drainage lines and firebreaks, which during the wet season are left to grow wild. These stretch from the backbone of the Drakensberg escarpment (including the Wolkberg Wilderness) to the 192 ha of WGG around Haenertsburg and a 60 ha WGG peninsular at Ebenezer Dam. The intent to proclaim the Haenertsburg Nature Reserve, albeit only 126 ha, shows progress by LEDET to uphold environmental priorities but more effort is needed in advising GTM and the private sector on the requirements of LEMA and NEMA and the importance of WGG. Environmental groups, similar to FroHG throughout South Africa, should see this case study as a success, even though lobbying for WGG is ongoing. This study provides an example of the various avenues that could be followed to help ensure better compliance and implementation of environmental legislation. An understanding of the appropriate legislation that applies to a situation and which tier of government is responsible is essential. Detailed record keeping of communications and raising awareness within civil society through the media can also be helpful. As the wheels of government move slowly, it is prudent to prepare for the long haul, to act as a group rather than as individuals and to choose environmental issues to lobby with careful research and specialist input. The intent to proclaim a WGG reserve and negotiations to designate FroHG as the management authority of the reserve are positive milestones for a publicprivate partnership and shows that civil society, scientists and provincial government can work together to achieve important conservation outcomes. Furthermore, the inclusion and recognition of environmental volunteer groups brings a diversity of skills and local knowledge to support important ongoing stewardship roles and is highly cost effective as it is based on volunteerism and community service.

\section{Acknowledgements}

A Postdoctoral Research Fellowship from the University of the Witwatersrand provided financial support. The Friends of the Haenertsburg Grassland are acknowledged for compiling an archive of information dating back to 1986 and pursuing the protection of these grasslands. Pieter Winter (South African National Biodiversity Institute), Dr Ute Schwaibold and Sylvie Kremer-Köhne (School of Animal, Plant and Environmental Sciences, University of the Witwatersrand), Advocate Jonathan Heher, Christo Rheeders Attorneys, the Centre for Environmental Rights and Tsholo Matlou, Department of Environmental Affairs, gave valued inputs. Cilla Wildgoose is thanked for assistance with Figures 1 and 2. Prof. Louis Changuion, previously in the History Department of the University of Limpopo, gave useful comments on the final manuscript and sourced the original town plan.

\section{Competing interests}

The authors declare that they have no financial or personal relationships which may have inappropriately influenced them in writing this article.

\section{Authors' contributions}

Both authors were responsible for conception and writing while C.M.D. collected and analysed data.

\section{References}

Anthony, B.P., Scott, P. \& Antypas, A., 2010, 'Sitting on the fence? Policies and practices in managing human-wildlife conflict in Limpopo Province, South Africa', Conservation and Society 8(3), 225-240. http://dx.doi.org/10.4103/09724923.73812

Brown, L.R. \& Cook, C.L., 2012, 'Preliminary ecological survey for the proposed bulk water pipeline, Haenertsburg-Polokwane, Limpopo Province', Royal Haskoning DHV, Lepelle Northern Water, unpublished.

Carbutt, C. \& Martindale, G., 2014, 'Temperate indigenous grassland gains in South Africa: Lessons being learned in a developing country', Parks 20(1), 104-125. http://dx.doi.org/10.2305/IUCN.CH.2014.PARKS-20-1.CC.en

Centre for Environmental Rights (CER), 2014, Numbers matter: Join us in reporting number of environmental rights violations, viewed 24 August 2015, from www. cer.org.za/news/numbers-matter-join-us-in-reporting-violations-ofenvironmental-rights

Centre for Environmental Rights (CER), 2015, Traditional healers lay criminal charges against mining company and its directors for environmental crimes, viewed 24 August 2015, from www.cer.org.za/news/traditional-healers-lay-criminalcharges-against-mining-company-and-its-directors-for-environmental-crimes

Changuion, L., 2007, Thar's gold in them thar hills: Haenertsburg 1887-1907, Review Printers, Polokwane.

Convention on biological diversity (CBD), 2014 'Fifth National Report for South Africa', viewed 24 August 2015, from http://www.cbd.int/doc/world/za/za-nr-05-en.pdf

Cowling, R.M. \& Wilhelm-Rechmann, A., 2007, 'Social assessment as a key to conservation success', Oryx 41, 135-136.

Department of Environmental Affairs (DEA), 2013, Long-Term Adaptation Scenarios Flagship Research Programme (LTAS) for South Africa, viewed 24 August 2015, from https://www.environment.gov.za/sites/default/files/docs/ summary_policymakers_bookV3.pdf

Department of Environmental Affairs (DEA), 2014, National Environmental Compliance and Enforcement Report 2013/14, Environmental Management Inspectorate Capacity Development and Support Directorate, viewed 24 August 2015, from https://www.environment.gov.za/sites/default/files/docs/ nationalenvironmental_complianceandenforcement_report2013_14.pdf

Desmet, P. \& Cowling, R., 2004, 'Using the species-area relationship to set baseline targets for conservation', Ecology and Society 9(2), 11, viewed 24 August 2015 from http://www.ecologyandsociety.org/vol9/iss2/art11

Desmet, P.G., Holness, S., Skowno, A. \& Egan, V.T., 2013, Limpopo conservation plan v.2: Technical report, viewed 24 August 2015, from http://bgis.sanbi.org/limpopo/ LCPV2_technicalReport_hires.pdf 
Dzerefos, C.M., 2004, 'Today, yesterday and tomorrow: The story of an African grassland', Veld and Flora 90(1), 18-19.

Dzerefos, C.M. \& Witkowski, E.T.F., 2001, 'Density and potential utilisation of medicinal grassland plants from Abe Bailey Nature Reserve, South Africa', Biodiversity \& Conservation 10, 1-22. http://dx.doi.org/10.1023/A:1013177628331

Dzerefos, C.M., Witkowski, E.T.F. \& Kremer-Köhne, S., 2016, 'Aiming for the biodiversity target with the social welfare arrow: Medicinal and other useful plants from critically endangered grassland ecosystem, Limpopo Province, South Africa' International Journal of Sustainable Development \& World Ecology. http://dx.doi. org/10.1080/13504509.2016.1174963

Fourie, L., Rouget, M. \& Lötter, M., 2015, 'Landscape connectivity of the grassland biome in Mpumalanga, South Africa', Austral Ecology 40, 67-76. http://dx.doi org/10.1111/aec.12169

Google Earth Pro V 7.1. (Google Earth Pro), 2014, Haenertsburg, Limpopo Province, $23^{\circ} 56^{\prime} 49^{\prime \prime}$ S $29^{\circ} 56^{\prime} 54^{\prime \prime}$ E, Eye alt 10240 feet, AfriGIS Pty (Ltd) CNES Astrium 2016 viewed 26 January 2016.

Low, A.B. \& Rebelo, A.G. (eds.), 1996, Vegetation of South Africa, Lesotho and Swaziland. A companion to the vegetation map of South Africa, Lesotho and Swaziland, Department of Environmental Affairs and Tourism, Pretoria.

Limpopo Provincial Gazette (LPG), 2015, 'Intention to declare attached respective land parcels as protected areas', 22(2609), viewed 08 March 2016, from http://www. gpwonline.co.za/Gazettes/Pages/Provincial-Gazettes-Limpopo.aspx? $\mathrm{p}=4$

Mfene, P.N., 2013, 'Public accountability: A professional basis for the South African public service', Administratio Publica 21(1), 6-23.

Moreroa, M.P., 2014, 'The legal implications of grassland as a threatened treasure: Analysis of Haenertsburg plains in South Africa', MSc thesis, Department of Environmental Law and Management, University of Limpopo.

Mucina, L. \& Geldenhuys, C.J., 2006, 'Afrotemperate, subtropical and azonal forests', in L. Mucina \& M.C. Rutherford (eds.), The vegetation of South Africa, Lesotho and Swaziland, pp. 601-602, Strelizia 19, South African Biodiversity Institute, Pretoria.

Mucina, L., Hoare, D.B., Lotter, M.C., Du Preez, P.J., Rutherford, M.C., Scott-Shaw, C.R et al., 2006, 'Grassland biome', in L. Mucina \& M.C. Rutherford (eds.), The vegetation of South Africa, Lesotho and Swaziland, pp. 349-412, Strelizia 19, South African Biodiversity Institute, Pretoria.

Niemandt, C., 2015, 'Anthropogenic impacts on the highly threatened Woodbush Granite Grasslands in Limpopo, South Africa', MSc thesis, Department of Plant Science, University of Pretoria.

Noss, R.F., 1990, 'Indicators for monitoring biodiversity: A hierarchical approach', Conservation Biology 4, 355-364. http://dx.doi.org/10.1111/j.1523-1739.1990. tb00309.x

Novellie, P., Biggs, H. \& Freitag-Ronaldson, S., 2013, Research and monitoring: Interface with legislation, policy and management, SANParks, viewed 24 August 2015, from www.sanparks.org/assets/docs/conservation/reports/2013_research_report.pdf

Opio-Odongo, J., 2013, State of the environment in Africa. UNEP. Sustainable Development Services, viewed 24 August 2015, from http://www.unep.org/pdf/ aeo3.pdf
Republic of South Africa (RSA), 2011, National list of ecosystems listed as threatened and in need of protection, Gazette No. 34809, Notice No. 1002, viewed 09 March 2016, from http://bgis.sanbi.org/ecosystems/Summary_\%20listed_ecosystems province.pdf

Republic of South Africa (RSA), 2013, The spatial planning and land use management act, no. 16 of 2013, Gazette No. 36730, Notice No. 559, viewed 15 March 2016, from http://www.gov.za/sites/www.gov.za/files/36730_5-8_Act16of20.pdf

Rossouw, N. \& Wiseman, K., 2004, 'Learning from the implementation of environmental public policy instruments after the first ten years of democracy in South Africa', Impact Assessment and Project Appraisal 22(2), 131-140. http:// dx.doi.org/10.3152/147154604781766012

Sango, I. \& Godwell, N., 2015, 'Climate change trends and environmental impacts in the Makonde. Communal Lands, Zimbabwe', South African Journal of Science 111(7/8). http://dx.doi.org/10.17159/sajs.2015/20140266

Seshoka, J., De Lange, W. \& Faysse, N., 2004, 'The transformation of irrigation boards into water user associations in South Africa: Case studies of the Lower Olifants, Great Letaba and Vaalharts Water User Associations', International Water Management Institute, viewed 24 August 2015, from http://www.iwmi.cgiar.org/ Management Institute, viewed 24 August 2015, from
Publications/Working_Papers/working/WOR72.pdf

Spatial development framework (SDF), 2009, Greater Tzaneen Local Municipality viewed 24 August 2015, from www.tzaneen.gov.za/tzaneen/docs/.../SPATIA $\% 20$ FRAMEWORK.pdf

Surveyor-General Office, 1887, Haenertsburg, Houtboschberg, Goudvelden, approved by the acting Surveyor-General, Pretoria, 05 March 1888.

Swemmer, L.K. \& Taljaard, S., 2011, 'SANParks, people and adaptive management: Understanding a diverse field of practice during changing times', Koedoe 53(2). $\mathrm{http}: / / \mathrm{dx}$.doi.org/10.4102/koedoe.v53i2.1017

Taylor, S.J. \& Atkinson, D., 2012, 'Delivering community benefits acts as insurance for the survival of small protected areas such as the Abe Bailey Nature Reserve, South Africa', Koedoe 54(1). http://dx.doi.org/10.4102/koedoe.v54i1.1043

Tesfaye, M.A., Bravo, F., Ruiz-Peinado, R., Pando, V. \& Bravo-Oviedo, A., 2016, 'Impact of changes in land use, species and ele on soil organic carbon and total nitrogen in Ethiopian Central Highlands', Geoderma 261, 70-79. http://dx.doi.org/10.1016/j. geoderma.2015.06.022

Thompson, D.I. \& Swemmer, A.M., 2014, 'Are grasslands doomed under global change? Triennial burning cannot prevent shrubland transformation of midaltitude South African grasslands', Scripta Botanica Belgica 52, 437.

Troskie, A., 2011, 'Squatters threaten scarce ecosystem', Letaba Herald 40(36), 1.

Wilhelm-Rechmann, A. \& Cowling, R.M., 2013, 'Local land use planning and the role of conservation: An example analyzing opportunities', South African Journal of Science, viewed 24 August 2015, from http://www.sajs.co.za/sites/default/files/ publications/pdf/Willhelm-Rechmannl_Research\%20art.pdf

Young, M., 2012, 'Are we greening our court rooms? An analysis of the recent decisions, in Magaliesburg Protection Association v MEC: Department of Agriculture, Conservation, Environment and Rural Development', South African Journal of Environmental Law and Law Policy 19(1), 63-73. 